\title{
THE IMPORTANCE OF ASSISTANT IN ECONOMIC EMPOWERMENT BASED ON BUSINESS ASSISTANCE: CASE STUDY ON WAHANA VISI INDONESIA ADP ECONOMIC PROGRAM, JATINEGARA
}

\author{
Bangun Kuncoro Haryo Aryanto \\ FISIP, University of Indonesia, thanatos.arya@gmail.com
}

Fitriyah

FISIP, University of Indonesia

\begin{abstract}
This paper discusses that one way to overcome poverty is by effective economic development. Economic development with a charitable nuance is only a short-term solution and it is feared that it cannot sustainably overcome poverty. Therefore, an inclusive empowerment process is needed, one of which is an economic empowerment program by WVI in the form of economic assistance to present the independence of the community with small and medium enterprises. Through a qualitative study in this paper researchers tries to provide an overview of the role of assistant in empowerment activities. In empowerment, assistant acts as a change agent. There are three things that make WVI as an assistant play an important role in empowerment. Assistant have a role as enablers where they enable change by placing the community as the subject of change. The assistant also plays a role in improving business competence. Lastly, to create sustainable conditions, the assistant needs to initiate the formation of a social system in the community as a vehicle for independent problem solving.
\end{abstract}

Keywords: Economic Empowerment, Business Assistance, Program Implementation 


\section{INTRODUCTION}

In Indonesia poverty is a problem that until now has not been able to be addressed thoroughly. Although national-scale development carries poverty alleviation as an outcome to be achieved, the people who are under the poverty line remain in the released statistical data. Poverty is seen as an economic inability to meet basic food and non-food needs, measured in terms of expenditure. (BPS, 2018)

Looking at the poverty line data issued by BPS, in 2018 the average poverty line is Rp. 425,770 / capita/month in urban areas and $\mathrm{Rp}$. 392.154 / capita/month in the countryside. (BPS, 2019) If a person does not have such a large amount for the cost of living for 1 month, the person is considered unable to fulfill his life needs (classified as poor).

If the poor population in Indonesia is recorded at around $25,674,580$ people belonging to the poor population, so many of the threatened population cannot fulfill their needs.

Table 1.1.Household Characteristics

\begin{tabular}{|l|r|r|}
\hline Household Characteristics & \multicolumn{1}{|l|}{ The Poor } & Non-Poor \\
\hline Average number of household members (people) & 4,57 & 3,69 \\
\hline The main source of income for the household (\%) & & \\
\hline a. Unemployment & 14,39 & 12,8 \\
\hline b. Work & 85,61 & 87,2 \\
\hline
\end{tabular}

Source: BPS, 2019

From the table above, it can be seen that the characteristics of poor households have more family members than non-poor households, and the percentage of unemployed groups is greater in poor households than in nonpoor households. Thus the common thread that can be taken is that households with unemployment are more likely to become poor households because they do not have income to meet the needs above the poverty line. Even worse, their family members tend to be bigger so they need more resources to fulfill their needs.

The development of the ability to be able to provide a decent income to meet needs is an effort that can be done.
Various types of development efforts have been made. However, to produce an outcome of increasing income, it needs more effort in community empowerment that is not only charitable (providing assistance only, short term) but must realize the independence of the community to be able to produce above the poverty line sustainably. One of them is by ensuring the population has a job with income above the family poverty line. Judging from the paradigmatic poverty, the development carried out at this time is more nuanced rather than productivity where this condition does not give rise to the urge to rise from adversity but continuous dependence. Besides, most of the target beneficiaries 
of poverty alleviation programs are seen as objects and not subjects. There needs to be an effort to explore the potential of the community to help itself (Santosa, 2012).

According to Heal, the concept of sustainability at least contains two dimensions: First is the dimension of time because sustainability is nothing but what will happen in the future. Second is the dimension of interaction between the economic system and natural and environmental resources systems. (Fauzi, 2004). From this understanding, it can be seen that empowerment that enables sustainability will try to synchronize between the management of resources owned by an efficient and effective community group towards the economic system and its environment.

Seeing the importance of sustainability in the empowerment effort undertaken, in this paper we will discuss how the process in the realization of this matter. The context to be taken as a case example is a program run by one of the Non-Government Organizations (NGOs), Wahana Visi Indonesia. In this program the goal is for parents/caregivers to meet the basic needs of children, with indicators:

$>$ Percentage $(\%)$ of parents or caregivers who can provide all children in the family, 0-18 years, with three important things, in their own way (production assets/income)

$>$ Percentage $(\%)$ of households with current savings/assets at least 1-time family expenses

To realize this, WVI runs business assistance to families with family members who are not active in carrying out economic activities. The program has been planned since 2008 and is still ongoing until the time of writing. But in its implementation, the program still has difficulties in achieving the planned outcome. As an indicator, there are many of assisted businesses which in the end are not actively trying. Of the 197 assisted entrepreneurs recruited only 74 were still active in 2013.

- It Has no savings. Many families with toddlers have no savings

- Do not have a side business. Many families who have children aged under five do not have a family side business to increase income

- Out of school children because of broken home family backgrounds, parents' attention is lacking in children's education, busy parents who work to meet the child's primary needs

- Low Income

- non-established work,

- Odd jobs (third place after employees and commerce)

- Low Expertise / Skills

- High Inflation

According to its objectives, the companion is needed to ensure empowerment goes according to its purpose, namely change. In making a planned change in community workers as actors of change or empowering the community, they have roles and skills. Karsidi (2001) explained that in assisting should refer to empowerment that refers to social and economic development whose paradigm is siding with the community. 
Look at the variety of results from the business assistance that is carried out. So in this paper, we will discuss the importance of the role of facilitators in making changes. This is done to be able to juxtapose the purpose of empowerment as a continuous process and practice of the actions taken.

Referring to the characteristics of poverty is a situation where needs are not met, understanding empowerment according to Shardlow in Adi (2001) argues that empowerment concerns individual problems, groups or communities try to control their own lives and try to shape the future as they wish. Another definition from Solomon in Lee (2001) suggests that empowerment is a process in which social workers are involved in a flow of activities with their clients that aims to reduce the powerlessness created by negative values of a group that gets a certain stigma.

The keys that must be opened in an empowerment process are in three dimensions, namely: empowerment leads to positive things about self and strength, construction of knowledge and capacity from social circles and reality from the environment around "subjects" and resource nurseries and strategies or functions that are more competent to achieve self-goal actualization.

The empowerment analogy in this paper is a program, so this program is bound by a period or not always the program is in the middle of a community that is the target of empowerment. This is due to limitations in both the resources and time that the executor has in the program to empower. Program implementers must be able to identify whether the empowerment carried out crucially has succeeded in increasing capacity and transferring resources to other individuals in a community. Dalrymple and Burke (Weiss \& Harris, 2001) suggest that the empowerment process cannot occur rigidly but is an ongoing process with a purpose that can change. Thus the flexibility of the program becomes flexible to support the effectiveness and efficiency of the program. Therefore empowerment cannot only be done as simply as possible in its activities and involves an instant transfer of resources but involves work through processes to try to reduce powerlessness from the client's experience (Weiss \& Harris, 2001).

This is more clearly illustrated in the definition of empowerment proposed by several other experts. Empowerment is a process, so it cannot be understood as a single project with beginning and end. A way or philosophy where the implementation and adjustment require guidance and a fairly long process (Wilson, 1996).

The concept of empowerment is based on ideas that place humans more than their world, (Payne in Adi, 2001) states that empowerment is essential:

"Helping clients gain power so that they can make decisions and determine the actions to be taken concerning themselves, by reducing the effects of personal and social obstacles in carrying out actions. This is done through increasing the capacity and confidence to use abilities, and by transferring their environmental 
capabilities to clients" [Adi, 2001]

Viewed from the previous understanding that empowerment is the process of planting seeds of knowledge to be able to manage resources effectively through the experience of empowering subjects themselves. The opinion of Wilson and Payne perfects the definition of empowerment which will lead to not only increasing ability, but there is an increased capacity to use these abilities by interacting between the subject and the environment. This statement shows that in empowerment activities each individual or community already has the power needed and helps that the individual can manage and develop their resources so that progress is achieved not only for individuals or groups themselves but also for the wider community.

Viewed from the definition and the purpose of the research of the scope of empowerment, it is known that community empowerment must be carried out both at the system, institutional and individual levels. In line with this, capacity building in efforts to develop the community must also be carried out at the same level, namely at the system, institutional, and individual levels. Capacity building at the system level encompasses a broad range of efforts and many emphasize the involvement of social workers in developing a system that favors the community. Within the community, the capacity building process is at the level of community institutions and the individual level of society.
The social worker in the context of this research is a companion wherein his work has the following identifiable roles:

Adi (2012) formulated that at least several roles are often adopted and developed by community workers, namely:

a. accelerating change

As an enabler, a change agent must position the community as the subject of change. Change actors help the community articulate community needs; identify problems; and develop the capacity to respond to problems.

b. Broker

Role as an intermediary means that actors of change are expected to be able to connect individuals or groups of people who need community assistance or services, but do not have access to where and how assistance or services are obtained.

c. Educator

Role as an educator means that change actors will convey the information needed by the community. Therefore, the perpetrators of change must have the ability to deliver clear information, besides that they must master well the theme of information to be presented. If not, it is necessary to connect with the right person to deliver the material. The perpetrators of change must always update their knowledge.

d. Expert

Change agents are expected to have the ability to provide input, advice and information support in various 
areas. The suggestions and suggestions given are not absolute but can be taken into consideration in the decision-making process.

e. Social Planner

A community worker needs the ability to do social planning, which is collecting data on social problems; analyze it to present a rational alternative action to deal with the problem. Planners develop programs, look for alternative sources of funds and develop consensus in groups of various interests and interests.

f. Advocate

Role as an advocate means that community workers carry out the function of a defense that represents groups of people who need help or services, but those who are supposed to provide services do not care about those needs.

g. Activist

Change actors are expected to be able to make more basic institutional changes. Empowerment is done by stimulating disadvantaged groups to be more organized.

\section{RESEARCH METHODOLOGY}

This research aimed to describe the empowerment carried out by WVI in community empowerment. For this reason, the approach to be used is a qualitative approach. The qualitative approach uses inductive thinking by looking at specific patterns (field findings) into a general pattern (concept/theory/model). The general pattern is a pattern that has been tested before and recognized by many people, in this study lies in the literature study and a special pattern is the actual situation found in the field.

This research took place in Jatinegara sub-district. This is because Jatinegara Subdistrict is the first subdistrict to be assisted by WVI, which has been calculated since 2008. There has been quite a lot of dynamics that have occurred whether it is successful in doing business or not. Therefore, it is expected that with a relatively long tempo of assistance, the data obtained is enough to describe empowerment comprehensively.

In this research, the researcher determined the informants based on the information needed. The required informants must have sufficient knowledge about how the empowerment implementation process from the start of the program runs, both from the subject of empowerment perspective and the perspective of the social worker. Besides, triangulation is needed to improve data validity. For this reason, several informants were appointed using purposive sampling from among groups: Staff program and assisted entrepreneurs. Purposive sampling is a type of sample that is useful in obtaining certain information, this sampling uses a person's judgment, so this sampling also aims to provide information that is following the theme in this research..

Data collection techniques used in this research were: Interview, in this research, aims to obtain information that is useful for completing information about the points that have been compiled in the interview guide (structured). Besides, interviews are used so that the results of the research obtained are a 
representation of the opinions of several parties from different perspectives to create triangulation in research.

In addition to primary data, this research also used secondary data. Secondary data used is data recorded from the activities carried out by the target community and WVI in the empowerment carried out. This document can also be the result of previous evaluations or research. The data is triangulation (evidence) of primary data or material in carrying out interpretations.

\section{FINDINGS AND DISCUSSION}

The empowerment efforts carried out by WVI in Jatinegara's target areas were by implementing an economic development (Ecodev) program. The ecodev program is based on the needs of the community in the region for additional income to meet needs, plus the unemployed family members have no activity. The reason is then formulated into a business assistance program, where family members will form a side business in the form of UMKM that produce certain goods.

At the planning stage, the WVI program identified that culinary business is the most potential business in the target area because of the large number of raw materials available and high demand. With certain mechanisms, until now WVI has succeeded in attracting more than 100 businesses to participate. In conducting business assistance, WVI implements it in several activities as follows:

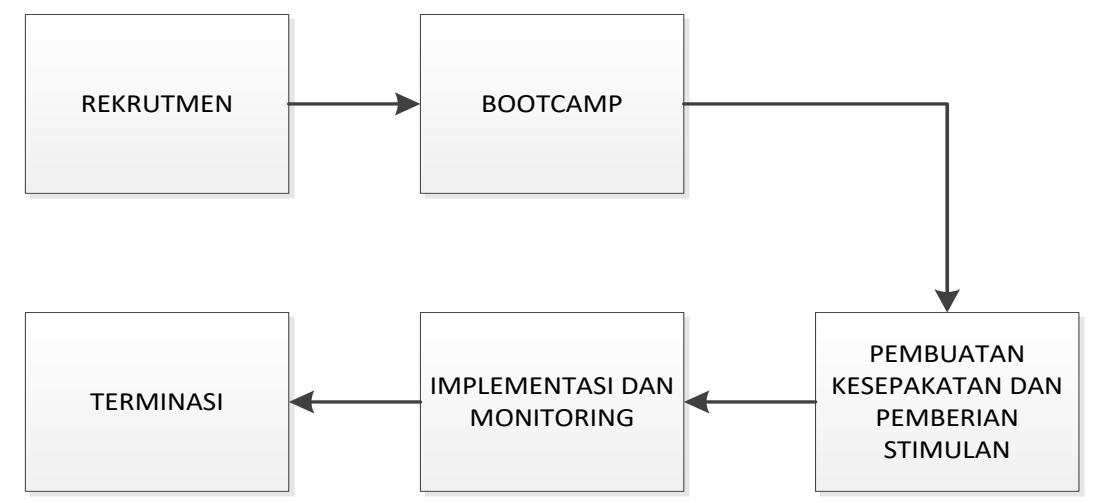

Picture 1.3. Roadmap Program

Source: WVI, 2017

The roadmap illustrates that the efforts made by WVI are:

1. Recruitment by organizing seminars which are usually held once a year for one class. At this stage, WVI gathers citizens with the potential to do business. At this stage, the companion plays the role of an enabler. The Companion helps the community identify problems and articulate community needs. In the program, the facilitator tried to recruit unproductive community members to be invited to run a business. As revealed "First we hold an assessment, we make a large seminar that is open to the public, while there is an assessment. This 
was opened by an invitation to the public, so the representatives of unemployed children were forced to participate in this seminar to be motivated to do business. The hope is that many people come from outside because we aim to reduce the level of poverty in the region, right, not just to our target families." Here it can be seen that WVI focuses more on instilling community motivation as the beginning of the mentoring process.

2. Bootcamp is a series of training and counseling where people participate in getting knowledge about entrepreneurship. Here the community is taught various forms of training in making products such as food or crafts, tailored to the abilities, interests, and decisions of the community to produce certain products. Besides, Bootcamp also implements an understanding of business planning skills, financial management, business certification, and marketing. As expressed by one of the companions: After that we did Bootcamp, it contained training, yes, training on entrepreneurship, marketing, how to start a business, business model, became a kind of training for basic entrepreneurs.... I already have a business, if you don't have a business you still have to join BootCamp, but later on, he must decide what business you want. There are also those who have businesses that change businesses. So basically he already has a minimum of 6 months business experience prioritized ... in bootcamp we correct their understanding so their needs are not just capital, they must know whether the product can sell in the market, later given capital but cannot be sold, we provide people to tester, we teach calculate the cost of goods sold, the business model. At this stage, WVI is an educator and expert who they provide knowledge and information needed in conducting business following the interests and needs of entrepreneurs.

3. Giving stimulants, in this section, the companion acts as an enabler who develops the ability of entrepreneurs to be able to produce. In the beginning, many entrepreneurs had limited capital to be able to run a business. The stimulus provided is not in the form of money, but rather the provision of equipment used in the production process in the form of loans that will later be returned to be used as capital for other businesses, as revealed by the companion: So we have a savings and loan system, we give the system its capital only through this stimulant and the savings and loan system for businesses that have developed to be able to help others. ... so we give loan stimulants, but the money doesn't go back to WVI but it goes to the people ... when they receive the stimulant there is a commitment form if they don't pay how if the mother doesn't sell or the mother sells there is also an obligation to pay it on the commitment form and paid to whom. Such a mechanism is intended to keep entrepreneurs running their 
businesses after being given stimulants.

4. After stimulants are given implementation and monitoring are carried out with visits from assistants and program staff and cadres with a frequency of about 4 times in one year. In its implementation, WVI seeks to develop consensus and systems in the community. This is done so that the community can solve economic problems that arise independently. For this reason, WVI initiated the establishment of an entrepreneur forum that overshadowed the assisted entrepreneurs. The entrepreneur forum has its independent management and its finances are regulated by the board of directors who are appointed entrepreneurs. This entrepreneur forum has several functions, namely: The function of monitoring, The entrepreneur forum has management that oversees entrepreneurs in the Jatinegara subdistrict. Because the area is large enough, the entrepreneur forum appoints the Regional Person in Charge (PJ Wilayah) for each Villages. PJ This region is responsible for knowing the issues that occur to entrepreneurs in the region. In the entrepreneur forum scheduled meetings are held every 2 months. This meeting is also used for brainstorming purposes of existing entrepreneurs. With this, it is expected that they can build their business network so that it is easy in coordination if there are entrepreneurs who need help in terms of finding solutions to problems encountered. The second function is the marketing function. From the entrepreneur forum that was formed, there was also an idea to create a joint store managed by the forum. Stores are hired to use funds from contributions and business stimulant payments. In this shop, the assisted entrepreneur can entrust the products produced for sale. In addition to shops, WVI along with entrepreneurs also jointly look for sales networks of their products. The entrepreneurial forum also functions in business development where forums are used to help small and medium entrepreneurs in access to licensing services which will be more difficult if done individually.

The results of the implementation of the process mentioned above show an achievement that has changed the economic condition of the family with the assisted business. Although, there are still entrepreneurs who in the end are no longer active in mentoring activities. As a further illustration, the following is a brief description of the current condition of entrepreneurs.

The first informant was a family from Mrs. T where he considered the assistance provided by WVI very helpful to him. She lives in a relatively small house with 4 family members, before his husband was a factory worker with relatively small money (around $\mathrm{Rp}$. 1,500,000 / month) currently increasing around the DKI Jakarta UMR. This income is deemed unable to support 2 children with adequate educational and 
nutritional needs. With the condition at that time she who could not support the business, WVI came to offer an economic development program by inviting them to do side business by carrying out the stages mentioned above.

Joined since the first batch of 2010, Mrs. T has now succeeded in helping the family economy despite the problem of lack of income "A month? Just a day, that morning, I will get 60 nights later. Not to mention if there is an order, it can reach 120. So a day can be more or less 200, huh, that's one thousand. It means that it can be 9 million a month. "Big income is enough to meet daily needs and the rest is saved." Successful, can school children up to high school now go to college. "'" For consumption and fulfill family nutrition, health, and nutrition increase". Mrs. $\mathrm{T}$ is one of the entrepreneurs who are active in Bootcamp activities carried out, every opportunity Mrs. T took the time to attend the training conducted and have high motivation to learn to make new products. It was evident from his frequent training of other entrepreneurs around her. At present, Mrs. T is still selling regularly by entrusting stores with forums and often getting orders for snack production not only from forums, but also from private orders.

The second informant was Mrs. E, one of the assisted entrepreneurs who was also the manager of the entrepreneur forum. She is one of the entrepreneurs with the type of catering business for various weddings and meetings. Her husband has retired and is currently actively supporting the business. Before joining the program he did not have the experience or ability to make decent dishes for sale. Then in the bootcamp, he was included in the training in making food at one of the professional cooking schools in Jakarta. Motivation emerged and self-confidence began to appear in my mother and established herself to open a catering business. The results obtained, at this time, Mrs E has had an operational vehicle that can be used for private vehicles as well as help distribute food at the event location. Other needs that can be fulfilled are that he can send his children to school even to college. Until now, the catering he runs can produce more than 3000 packs in one event with a variety of dishes, while he is active in the management of the entrepreneur forum by arranging the PJ Region to monitor the sustainability of each of the assisted businesses. She is also active as a trainer to teach new entrepreneurs as part of the knowledge sharing process.

The third informant was Mrs. B, entrepreneurs who joined were newer compared to the two previous informants. Therefore, the business achievements made were not as big as the two previous informants. Mrs. B chose to open a food business such as ordering meatballs, sponge cakes, small cakes (for a shop) or birthday cakes. At first, they were active in WVI activities and forums, with sufficient business income to help meet children's needs. However, at one point he stopped being active because he had to take care of a newborn baby. Another reason for the failure of the product to be deposited with the store together made it reluctant to leave food there. Feeling they did not get the solution, so they 
were not actively accepting production orders from the forum, which made their turnover decrease and eventually vacuumed, this made the family's economic conditions decline.

James Midgley (Midgley in Adi, 2013) defines social welfare as a condition or condition of human life that is created when various social problems can be managed properly: when human needs can be fulfilled, and when social opportunities can be maximized. In the context of this paper if empowerment is a process of planting seeds of knowledge to be able to manage resources effectively through the experience of subject empowerment itself. So the empowerment program carried out by WVI is a process that supports the creation of social welfare in the community because the results achieved show symptoms where there is a change in community capacity in efforts to solve problems, fulfill needs, and opportunities to carry out economic activities.

In the previous conceptual framework, it was explained about the importance of facilitators as agents of change. Based on the findings of the program conducted by WVI, the existence of a companion can be a determinant in the success of change.

First, companion plays an important role as an enabler where each entrepreneur who has an idea of doing business based on their abilities and interests, types and training materials to increase entrepreneur competency are chosen and carried out by the community, WVI only looks for the right sources and assists in accommodation organizing training. In terms of marketing, WVI acts as a market assessment, where it is found that processed chicken is the most appropriate product to produce given the availability of markets and easy raw materials. On several occasions, WVI helped the community in finding joint markets, seen in the provision of orders managed by entrepreneur forums originating from WVI, as well as the participation of employers in several bazaar events that were the result of community collaboration and WVI. However, along with the dynamics, marketing began to be carried out independently by the community as seen from the walk of the entrepreneur forum in utilizing the capital for joint store opening and trademark manufacturing. Here the companion is aware of his role and puts the community as the subject of empowerment, not an object.

Second, facilitators play an important role in increasing entrepreneur capacity, namely economic potential through stimulant efforts or business training. The process of recruitment and training provided sees potential and improves entrepreneur competency from those who cannot be able, from those who do not believe in being able to do business. This can be seen from the recognition of the entrepreneurs mentioned above that previously they did not have a business because they tended not to have capable capabilities for production. This situation changes after the entrepreneur tries to take part in the training, and tries to do business. Although the results are not instant, the existing process can provide choices to meet family needs, where previously it 
was difficult to fulfill needs because there was no choice but to use one family member money to meet all needs. The problem is that the income is not enough to meet family nutrition and children's education. With the existence of an assisted business which ultimately increases family income significantly makes efforts to meet needs become more likely to be done.

Third, facilitators play an important role in creating a healthy system for the community to develop, good interaction between humans and their environment. Heal in Fauzi (2004) explains that sustainability contains two dimensions, namely the dimension of time because sustainability is nothing but what will happen in the future. Second, is the dimension of interaction between economic systems and resource systems and the environment. In terms of business continuity, WVI initiated the establishment of an entrepreneur forum

\section{CONCLUSION}

Economic development is one way to alleviate poverty. However, it is feared that economic development, which is only charitable, cannot sustainably overcome poverty, as evidenced by the fact that there are still many people who are below the poverty line. Therefore, in realizing a development process that should be needed an empowerment process that refers to the concept of sustainability.

One of the programs discussed in this research was conducted by Wahana Visi Indonesia, an NGO that has long been engaged in realizing prosperity for children. In this paper, it is discussed that WVI runs a community economic to keep the business going. In this forum, it is expected that there will be continuity between how problems in business meet with solutions discussed in business meetings. In the meeting held every two months by all forum members identified problems encountered by entrepreneurs and tried to find a joint solution. In terms of capital the forum has cash that can be used to help capital entrepreneurs. In addition, there are savings groups that are a family favorite in seeking venture capital because the interest is relatively small. However, making a consultative system is not an easy job. Businesses that are run are not always smooth. The findings described earlier illustrate how disagreements can trigger conflict in the forum. There needs to be a mechanism that maintains the representation of opinions of all forum members to maintain the continuity of the forum itself.

development program that is not charitable in the form of assistance to bring about community independence. In the program being run, some stages that are used as models in its application. Where in the general stages of the function described in empowerment namely identification of needs, planting competencies, and the formation of social systems in the community.

There are three arguments where the companion has an important role in the process of economic empowerment. First, assistants help the process of developing individual entrepreneurial capacities by interpreting individuals not only as objects of empowerment, but as subjects of empowerment. Second, the 
facilitator strengthens the economic potential that is carried out through the provision of appropriate capital, and the provision of training to improve the competency of the entrepreneur. It is intended that the client has skills that enable him to do something productively. Third, the companion plays a role in creating a healthy system for the community to develop, good interaction between humans and the environment. This can be done by creating a friendly social system with the formation of institutions in the surrounding community that accommodates problemsolving consultations among its members. The existence of institutions is expected to be social capital where there is a sense of mutual trust among its members so that the tendency for cooperation can emerge.

\section{REFERENCES}

Adi, Isbandi Rukminto. (2001). Pemberdayaan, Pengembangan Masyarakat dan Intervensi Komunitas: Pengantar Pada Pemikiran dan Pendekatan Praktis. Jakarta: Fakultas Ekonomi UI.

Adi, Isbandi Rukminto. (2013). Kesejahteraan Sosial (Pekerjaan Sosial, Pembangunan Sosial, dan kajian Pembangunan), Depok: Rajawali Pers.

Fauzi.A. (2004). Ekonomi Sumber Daya Alam dan Lingkungan, Teori dan Aplikasi, Gramedia Pustaka Utama, Jakarta

Lee, Judith A.B. (2001). The Empowerment Approach to Social Work Practice: Building the beloved community Second edition. New York: Columbia University Press.

Santosa, Imam. (2012) Konstruksi Akar Permasalahan Dan Solusi Strategis Kemiskinan Di Perkotaan.

Weiss, M. J., \& Harris, S. L. (2001). Teaching social skills to people with autism. Behavior Modification.

Wilson, P. (1996). Empowerment: Community economic development from the inside out. Urban Studies

BPS. (2019). Karakteristik Rumah Tangga Miskin dan Rumah Tangga Tidak Miskin 2013-2017

BPS. (2019). Jumlah Penduduk Miskin Menurut Provinsi, 2007-2018.

BPS. (2019). Garis Kemiskinan Menurut Provinsi, 2013 - 2018. 